\title{
Unusual Anterior Neck Swelling: Cervical Spinal Cord Schwannoma
}

\section{Inchaço anterior incomum do pescoço: Schwannoma da medula espinhal cervical}

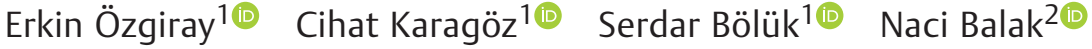 \\ ${ }^{1}$ Department of Neurosurgery, Ege University, Medical Faculty, \\ Izmir, Turkey \\ 2 Department of Neurosurgery, Istanbul Medeniyet University, \\ Address for correspondence Naci Balak, MD, Department of \\ Neurosurgery, Istanbul Medeniyet University, Göztepe Hospital, \\ Istanbul, Turkey (e-mail: naci.balak@gmail.com).
} Göztepe Hospital, Istanbul, Turkey

Arq Bras Neurocir

\section{Abstract \\ Keywords \\ - cervical neuroma \\ - dumbbell schwannoma \\ - neck mass \\ - neck swelling \\ - spinal schwannoma}

\section{Resumo}

received

May 1, 2021

accepted

August 6, 2021
Schwannomas are typically solitary, well-encapsulated, benign tumors running along or attached to a nerve. An intradural-extramedullary cervical spinal schwannoma, which first manifests as a swelling in the anterior neck, has not been reported to the best of our knowledge. We present the case of a 69-year-old patient complaining of a gradually worsening painful left cervical swelling for over 8 years. First, a posterior spinal midline approach was performed for the resection of the tumor and the tumor portion in the vertebral canal was totally removed. The second operation, the anterolateral approach, was planned to be executed in a second surgical session. The patient was discharged from the hospital without neurological deficits. Histopathological diagnosis was a schwannoma. The first aim of surgery is to treat neurological deficits in patients with cervical intraspinal schwannomas with/without extension into the extravertebral paravertebral neck regions. The surgical strategy combines the posterior midline and the anterolateral cervical approaches in the same session or at different times.

Schwannomas são tipicamente tumores solitários, bem encapsulados e benignos que correm ao longo ou aderem a um nervo. Até onde sabemos, um schwannoma espinhal cervical intradural-extramedular que se manifesta pela primeira vez como um inchaço na região anterior do pescoço não foi relatado. Apresentamos o caso de um paciente de 69 anos com queixa de inchaço cervical esquerdo doloroso de piora gradual há mais de 8 anos. Primeiramente, uma abordagem da linha média da coluna vertebral posterior foi realizada para a ressecção do tumor, e a porção do tumor no canal
DOI https://doi.org/

10.1055/s-0041-1739277. ISSN 0103-5355. (c) 2021. Sociedade Brasileira de Neurocirurgia. All rights reserved. This is an open access article published by Thieme under the terms of the Creative Commons Attribution-NonDerivative-NonCommercial-License, permitting copying and reproduction so long as the original work is given appropriate credit. Contents may not be used for commercial purposes, or adapted, remixed, transformed or built upon. (https://creativecommons.org/ licenses/by-nc-nd/4.0/)

Thieme Revinter Publicações Ltda., Rua do Matoso 170, Rio de Janeiro, RJ, CEP 20270-135, Brazil 


\author{
Palavras-chave \\ - neuroma cervical \\ - schwannoma com \\ halteres \\ - massa cervical \\ - inchaço do pescoço \\ - schwannoma espinhal
}

vertebral foi totalmente removida. A segunda operação, via anterolateral, foi planejada para ser realizada em uma segunda sessão cirúrgica. O paciente recebeu alta hospitalar sem déficits neurológicos. O diagnóstico histopatológico foi um schwannoma. O primeiro objetivo da cirurgia é tratar déficits neurológicos em pacientes com schwannomas intraespinhais cervicais com/sem extensão para as regiões extravertebrais do pescoço paravertebral. A estratégia cirúrgica combina a abordagem da linha média posterior e a abordagem anterolateral cervical na mesma sessão ou em momentos diferentes.

\section{Introduction}

Schwannomas are benign mesenchymal tumoral masses that originate from Schwann cells on the peripheral nerve sheath, including the spinal dorsal nerve roots. ${ }^{1-3}$ Spinal schwannomas occur rarely and compress neighboring structures in the neck region. ${ }^{4}$ An intradural-extramedullary schwannoma with a solitary extradural component anteriorly extended is a very rare entity. ${ }^{5,6}$ It is unusual for an intraspinal schwannoma to present with a swelling in the neck. To the best of our knowledge, an intradural-extramedullary cervical spinal schwannoma which first manifests as a swelling in the anterior neck region has not been reported.

\section{Clinical Presentation}

\section{Patient Characteristics}

A 69-year-old right-handed man presented to our department complaining of a gradually worsening painful left anterior cervical swelling over 8 years. The mass was insidious and gradually increasing in size. Physical examination of the patient revealed an unusual palpable swelling, which was hard, non-pulsatile, and painless, in the left anterior neck region. The remainder of the physical examination was normal.

On neurological examination, muscle strength was normal and neither sensory deficiency nor pathological reflex was present. The patient had no dysphonia, syncopal attacks, dysphagia, or dyspnea. The magnetic resonance imaging (MRI) revealed an intradural extramedullary tumoral mass at the C2-C3 level(-Fig. 1 A-B). The tumor, which extends to

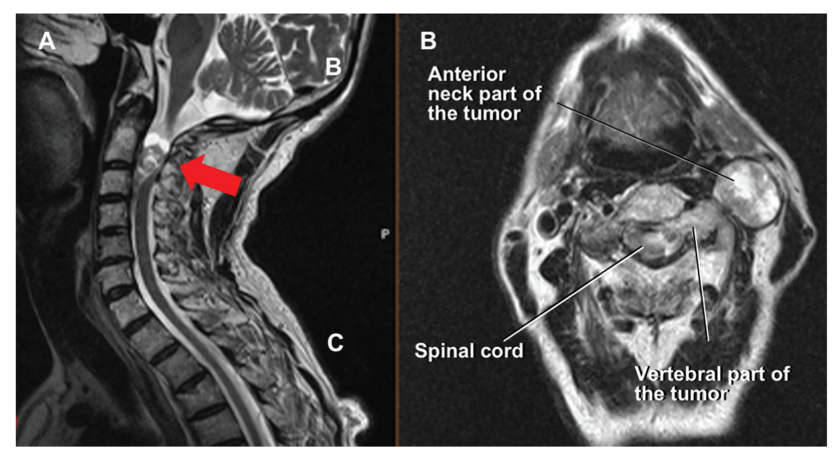

Fig. 1 Preoperative magnetic resonance images (MRIs): T2-weighted MRI in sagittal (A) and axial planes (B) and at the level of $C 3$ corpus shows the tumor. (A; arrow) the anterior neck region, was hypointense on T1-weighted magnetic resonance imaging (MRI) scans and hyperintense on T2-weighted MRI scans. It enhanced heterogeneously after administration of contrast media. The anterior--posterior diameter of the lesion has reached $\sim 3 \mathrm{~cm}$, with the spinal canal and the extension in the neural foramen, the total size reaching $6 \mathrm{~cm}$. Computed tomography (CT) angiography showed no vascularization in the tumor, but an anterior displacement of the carotid sheath.

\section{Surgical Procedure}

Our surgical strategy combines the posterior midline approach and the anterolateral cervical approach at different times. First, a posterior spinal midline approach was performed for the resection of the tumor. The second operation, the anterolateral approach, was planned to be executed in a second surgical session. In the first operation, under general anesthesia, neuro-monitorization was used to monitor the intraoperative action potential of the trapezius and the upper limb muscles. A three-pin head holder was applied, and the patient was positioned prone. A two-level laminectomy at C2 and C3 was performed following a midline incision and a standard opening. A surgical microscope was introduced, and a longitudinal dural incision was made. This revealed the intradural part of the tumor, which was located under the C3 dorsal root and dentate ligaments (-Fig. 2). The tumor extended anterolaterally from the spinal cord, and this was evidenced by observation of the adjacent subarachnoid space. We removed the tumor in piecemeal fashion following a central debulking until total resection of the intraspinal part of the tumor was achieved.

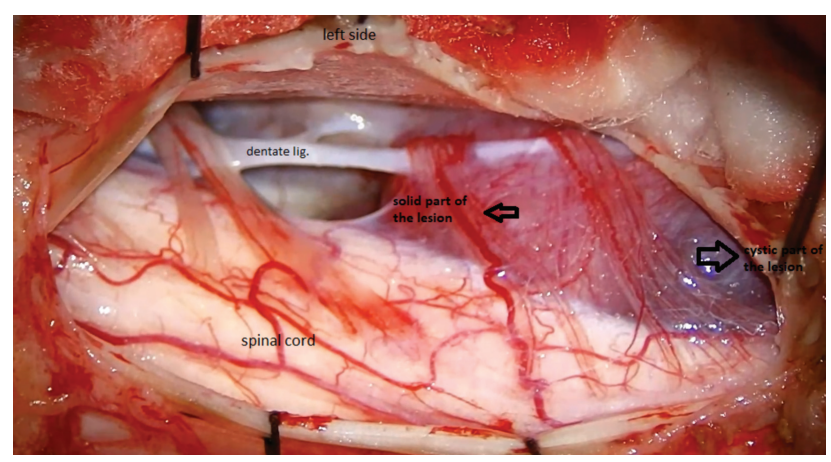

Fig. 2 Intraoperative view 


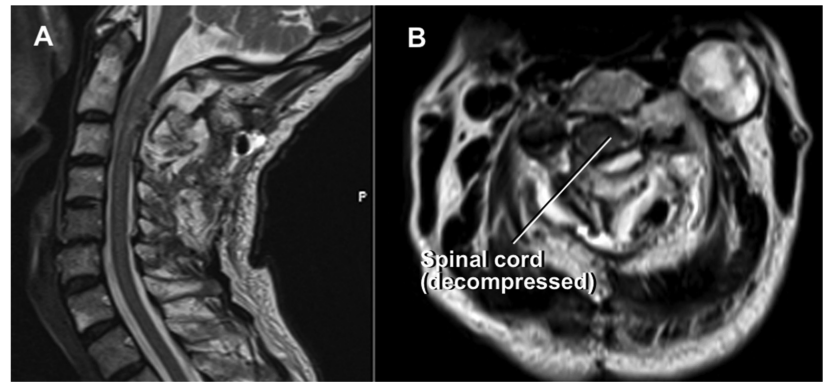

Fig. 3 Postoperative magnetic resonance images (MRIs). T2weighted MRI in sagittal (A) and axial planes (B) and at the level of C3 corpus. The spinal cord is seen to be decompressed.

An ultrasonic aspirator was employed during tumor removal, which turned out to be insufficient due to a semi-fibrotic structure of the lesion. The tumor was not extremely hemorrhagic, and no evidence of tumor necrosis was observed either. Intraoperatively, it was consistent with a schwannoma, which was later confirmed with the histopathological examination.

\section{Postoperative follow-up}

Postoperative MRI images demonstrated a total removal of the tumor in the vertebral canal with the extraspinal anterior part of the tumor left untouched. (-Fig. 3). The patient was discharged from the hospital without neurological deficits.

\section{Discussion}

In literature, there are rare case reports of schwannoma, which manifest with cervical swelling, including the tongue, thyroid gland, intraparotid gland facial nerve, the cervical sympathetic chain, brachial plexus, and vagal nerve schwannomas.,7-14 But the anteriorly extended intradural extramedullary cervical schwannoma is uncommon. ${ }^{15,16}$ In addition to this infrequency, in our case, the intradural extramedullary lesion has an anterior extension, which causes observable and palpable neck swelling. This clinical presentation for a spinal schwannoma is atypical.

To understand head and neck surgery and to perform systematic and safe excision of tumors, training in neuroanatomy of the neck region is essential. ${ }^{17-20}$ A detailed knowledge of the complex topographic relationships between muscles, blood vessels, nerves, and lymph nodes will enable the surgeon to safely perform difficult and risky dissection in the head and neck region. In addition, a good knowledge of both anterior and posterior approaches-as well as their variations-to the neck region is crucial in choosing the most appropriate surgical method. Conventional treatment for spinal tumors includes open laminectomy. ${ }^{21}$ However, a wide variety of alternative minimally invasive surgical techniques including laminoplasty and unilateral hemilaminectomy are used. $^{21-23}$
The diagnosis of cervical schwannoma is difficult due to the fact that they are slowly growing tumors, and the medical history and clinical examination are not specific. ${ }^{14}$ The symptoms are local pain or loss of sensation/strength due to intraspinal cervical spinal cord compression. However, asymptomatically, their volume may gradually increase and, although rarely, they may appear as cervical swelling. ${ }^{24,25}$ After this stage, signs and symptoms are generally related to the size of the schwannoma, and symptoms such as dysphagia and dyspnea may appear due to the compression of the surrounding anatomical structures. ${ }^{26}$ Magnetic resonance imaging and computed tomography (CT) angiography are very useful diagnostic tools for surgical planning, as they show the extension and vascularity of the tumor and its relationship with important functional structures in the neck.

\section{Conclusions}

The first aim of surgery is to treat neurological deficits in cervical intraspinal schwannomas with extension into the extra-vertebral paravertebral neck regions. Therefore, the surgical strategy combines the posterior midline and the anterolateral cervical approaches in the same session or at different times.

\section{Ethical Issues}

The ethical issues for the present study involving human subjects have been carefully considered in line with the Declaration of Helsinki (1964).

\section{Financial Support}

None.

\section{Authors' Contributions}

Erkin Özgiray: Conceived the idea, collected data, performed the analysis, interpreted the results, wrote the text, performed a literature search, critically reviewed the intellectual content, and revised the text.

Cihat Karagöz: Analyzed and designed data, interpreted the results, performed a literature search, revised the text, and critically reviewed the intellectual content.

Serdar Bölüik: Analyzed and designed data, interpreted the results, performed a literature search, and revised the text.

Naci Balak: Analyzed and designed data, interpreted the results, performed a literature search, revised the text, and critically reviewed the intellectual content.

\section{Patient Consent}

The patient signed the informed consent agreement of clinical images and data for medical use.

Conflict of Intersts

The authors have no conflict of interests to declare.

Acknowledgments

None. 


\section{References}

1 Altaş M, Cerçi A, Silav G, et al. Microsurgical management of nonneurofibromatosis spinal schwannoma. Neurocirugia (Astur) 2013; 24(06):244-249

2 Takashima H, Takebayashi T, Yoshimoto M, et al. Differentiating spinal intradural-extramedullary schwannoma from meningioma using MRI $\mathrm{T}_{2}$ weighted images. Br J Radiol 2018;91:20180262

3 Adouly T, Adnane C, Oubahmane T, et al. An unusual giant schwannoma of cervical sympathetic chain: a case report. J Med Case Reports 2016;10:1-4

4 Lot G, George B. Cervical neuromas with extradural components: surgical management in a series of 57 patients. Neurosurgery 1997;41(04):813-820, discussion 820-822

5 Terada Y, Toda H, Yokote A, Iwasaki K. A Mobile Schwannoma of the Cervical Spinal Cord: Case Report and Review of the Literature. Neurosurgery 2016;78(01):E156-E159

6 Kumar SA, Kumar M, Malgonde M. Dumbbell-shaped neurofibroma of the upper thoracic spine: A case report. South Asian J Cancer 2013;2(04):226

7 Cavallaro G, Pattaro G, Iorio O, Avallone M, Silecchia G. A literature review on surgery for cervical vagal schwannomas. World J Surg Oncol 2015;13:1-4

$8 \mathrm{Xu} \mathrm{XQ}$ Hong T, Zheng CJ. Schwannoma originating from the recurrent laryngeal nerve in a thyroid cancer patient: A case report and review of the literature. World J Clin Cases 2018;6(16):1202-1205

9 Kang JY, Yi KS, Cha SH, et al. Schwannoma of the thyroid bed: A case report and review of the literature. Medicine (Baltimore) 2020;99(05):e18814

10 Najeeb T, Khan M. Sympathetic Chain Schwannoma Resembling Carotid Body Tumour. J Coll Physicians Surg Pak 2016;26)6, Suppl):S68-S70

11 Petruzzi G, Costantino A, Arosio AD, et al. Transoral Robotic Surgery in the Management of a Tongue Base Schwannoma. J Craniofac Surg 2020;31(04):e411-e413

12 Ranjan S, Arora N, Sethi D, Kaur D, Sethi G. Schwannoma of the Brachial Plexus: A Rare Case Report. Iran J Otorhinolaryngol 2020; 32(111):243-247

13 Seo BF, Choi HJ, Seo KJ, Jung SN. Intraparotid facial nerve schwannomas. Arch Craniofac Surg 2019;20(01):71-74

14 Behuria S, Rout TK, Pattanayak S. Diagnosis and management of schwannomas originating from the cervical vagus nerve. Ann $R$ Coll Surg Engl 2015;97(02):92-97
15 Goga C, Türe U. The anterolateral transforaminal approach to a dumbbell schwannoma of the C3 nerve root: a 3-dimensional operative video. Operative Neurosurgery 2015;11(01):201

16 Nguyen VN, Khan NR, Arnautović KI. Microsurgical Resection of a C1-C2 Dumbbell and Ventral Cervical Schwannoma: 2-Dimensional Operative Video. Oper Neurosurg (Hagerstown) 2020;19 (04):E407-E408

17 Lucioni M. Practical Guide to Neck Dissection. Berlin Heidelberg: Springer-Verlag; 2007

18 Denli Yalvac ES, Baran O, Aydin AE, Balak N, Tanriover N. Surgical Pitfalls in Carotid Endarterectomy: A New Step-By-Step Approach. J Craniofac Surg 2018;29(08):2337-2343

19 Balak N, Baran O, Denli Yalvac ES, Esen Aydin A, Tanriover N. Surgical technique for the protection of the cervical sympathetic trunk in anterolateral oblique corpectomy: A new cadaveric demonstration. J Clin Neurosci 2019;63:267-271

20 Denli Yalvac ES, Balak N, Atalay B, et al. A New Method for Determining the Level of the Carotid Artery Bifurcation. J Craniofac Surg 2019;30(06):e523-e527

21 Tredway TL, Santiago P, Hrubes MR, Song JK, Christie SD, Fessler RG. Minimally invasive resection of intradural-extramedullary spinal neoplasms. Neurosurgery 2006;58(01):ONS52-ONS58, discussion ONS52-ONS58

22 Balak N. Unilateral partial hemilaminectomy in the removal of a large spinal ependymoma. Spine J 2008;8(06):1030-1036

23 Balak N. Quadrantectomy for resection of spinal ependymomas with a new classification of unilateral approaches regarding bone drilling and the use of a new tool: The Balak ball-tipped water jet dissector. Interdiscip Neurosurg 2016;5:18-25

24 Furukawa M, Furukawa MK, Katoh K, Tsukuda M. Differentiation between schwannoma of the vagus nerve and schwannoma of the cervical sympathetic chain by imaging diagnosis. Laryngoscope 1996;106(12 Pt 1):1548-1552

25 Pokharel A, Rao TS, Basnet P, Pandey B, Mayya NJ, Jaiswal S. Extradural cervical spinal schwannoma in a child: a case report and review of the literature. J Med Case Reports 2019; 13(01):1-5

26 Zhang H, Cai C, Wang S, Liu H, Ye Y, Chen X. Extracranial head and neck schwannomas: a clinical analysis of 33 patients. Laryngoscope $2007 ; 117(02): 278-281$ 